\title{
Evaluation of IBA Labels on Vegetative and Rooting Performance of Dormant Cuttings of Plum Cv Santa Rosa under Mist
}

\author{
Amit Kotiyal $^{1^{*}}$ and Anant Ram Nautiyal ${ }^{2}$ \\ ${ }^{1}$ Department of Horticulture, HNBGU, Srinagar Garhwal-246174, Uttarakhand, India \\ ${ }^{2}$ High Altitude Plant Physiology Research Centre (HAPPRC), HNBGU, Srinagar Garhwal- \\ 246174, Uttarakhand, India \\ *Corresponding author
}

\section{A B S T R A C T}

Keywords

Indole 3-butyric acid (IBA), Santa Rosa plum, Cuttings

Article Info

Accepted:

07 September 2019

Available Online:

10 October 2019
Commercially plum is multiplied by budding and grafting which is a difficult exercise for unskilled farmers. Therefore, multiplication through semi hard wood stem cuttings in mist house has been studied with six treatments of indole-3-butyric acid concentrations (0, 1000, 1500, 2000, 2500 and $3000 \mathrm{ppm}$ ) at Horticulture Research Center, HNBGU, Srinagar Garhwal, Uttarakhand during the year 2016-17 under Ph.D. discipline. Cuttings were treated by quick dip ( 2 minute) method and planted in disposable glass. All observations were registered after 90 days of planting the cuttings under mist chamber. Among all the IBA treatments, cuttings treated with 1000 ppm IBA concentration resulted significantly highest in respect of fresh weight of shoot $(0.26 \mathrm{~g})$, dry weight of shoot $(0.099 \mathrm{~g})$, rooting percentage $(71.67 \%)$, fresh weight of root $(0.123 \mathrm{~g})$ and dry weight of root $(0.028 \mathrm{~g})$ followed by $1500 \mathrm{ppm}$ IBA treatment. The pattern of root and shoot growth indicated that their growth is affected by IBA level as well as by the growth of each other.

\section{Introduction}

Plums are one of the widely cultivated stone fruits and characterized as a firm flesh with sweet, sour, juicy and delicious flavour fruit. They can be consumed fresh but are commonly processed, mostly into prunes or distilled drinks (Catherine and Ginies, 2009). Japanese plums are well adapted in the hills of northern states of India. Among different cultivars Santa Rosa is delicious fruit cultivar of Japanese plum. It requires 400-700 hrs of chilling temperature. Multiplication of these progeny for Propagation is important aspect in fruit cultivation because it is required for multiplication of progeny of same cultivar. Commercially plum is propagated by budding and grafting which requires high skilled man 
power where as rate of success is very less (Ananda 1993). Besides this the availability and selection of corret scion and rootstock makes it bottle neck of propagation. Stem cutting is the simplest method of propagation which needs very less care and skill, and helps for shallow rooted plant which causes dwarfing effect and makes it suitable for high density plantation. But some woody plants have limitation in regeneration of rooting through cuttings. There are several factors known which affect rooting in woody species such as wounding of cuttings, air environment, substrate, genotype, season and plant growth regulators. Among all these factors auxins play important role in rooting regeneration of stem cutting of fruit plants (Canli and Bozkurt, 2009). In a study Narula (2018) reported that stem cuttings of Kala Amritsari plum regenerate maximum shoot and root growth in 2000 ppm IBA treatment among all of the IBA treatments. In temperate region Santa Rosa plants grow very well but are found less successful in juvenile stage due to frost injury. So these plants may be grown under mist in subtropical and temperate condition. Therefore, keeping the above factors in view, the present study has been planned to check the performance of auxin concentration levels in plum cuttings for having true plant progenies.

\section{Materials and Methods}

The present investigation has been carried out in the Horticultural Research Centre, and Department of Horticulture, H.N.B. Garhwal University, Srinagar (Garhwal), Uttarakhand, during the year 2016-17. Santa Rosa plum cuttings were prepared of $16 \mathrm{~cm}$ length and 0.4 to $0.6 \mathrm{~mm}$ diameter from more than 10 year old trees of Santa Rosa plum established at Horticultural Research Centre, Chauras Srinagar Garhwal. Prepared cuttings were treated with six IBA concentrations $(0,1000$, 1500, 2000, 2500 and $3000 \mathrm{ppm}$ ) and planted on $1^{\text {st }}$ December under the mist chamber. The cuttings were planted in disposable glass of 200 gm capacity filled with (Coco peat, Vermi compost, sand and soil @ 2:2:1:1 portion) rooting media. An intermittent mist system was set at $22 \pm 2{ }^{0} \mathrm{C}$ temperature and 79-85\% relative humidity and mist were relayed at 30 minute interval for 20 second. The experiment was organized according to randomized block design (RBD). All observations of cuttings were recorded after 90 days of planting the cuttings under mist of each treatment.

\section{Results and Discussion}

In the present study, different IBA concentrations in term of fresh and dry weight of shoot, rooting percentage, fresh and dry weight of root has been noticed significantly which are presented in Table 1 with the mean values of the observations.

\section{Fresh and dry weight of shoot}

The analyzed data reveals that fresh and dry weight of shoot in Santa Rosa plum cutting under mist condition has significantly been influenced by auxin concentration level. The maximum fresh weight of shoot $(0.26 \mathrm{~g})$ was observed in 1000 ppm IBA followed by 1500 ppm (0.25 g), 2000 ppm (0.23 g) while minimum was in $3000 \mathrm{ppm}(0.13 \mathrm{~g})$ followed by $2500 \mathrm{ppm}(0.20 \mathrm{~g})$ and control $(0.21 \mathrm{~g})$. Dry weight of shoot was recorded maximum in $1000 \mathrm{ppm}$ IBA $(0.099 \mathrm{~g})$ followed by 1500 ppm (0.096 g), control (0.089 g) and minimum in $3000 \mathrm{ppm}(0.038 \mathrm{~g})$ followed by $2500 \mathrm{ppm}$ $(0.083 \mathrm{~g})$ and $2000 \mathrm{ppm}(0.088 \mathrm{~g})$.

Growth in weight may probably be due to increased number of leaves and girth of shoot which could have resulted in more amount of dry matter accumulation as a consequence of higher amount of photosynthesis. Similar findings were observed by Jana et al. (2015) who reported maximum $75.40 \mathrm{~g}$ fresh weight 
of shoot in Asian pear cutting with $1000 \mathrm{ppm}$ IBA concentration followed by $500 \mathrm{ppm}$ and $1500 \mathrm{ppm}$, while the minimum was in control. In another study, Rajeshwari et al. (2015) reported the maximum $9.64 \mathrm{~g}$ fresh weight and $6.41 \mathrm{~g}$ dry weight of shoot in drumstick cuttings in $1500 \mathrm{ppm}$ concentration among four treatments $(0,500,1000$ and $1500 \mathrm{ppm}$ IBA) of IBA.

\section{Rooting percentage}

Rooting percentage has been found significantly maximum in $1000 \mathrm{ppm}(71.67 \%)$ followed by $1500 \mathrm{ppm}$ (68.33\%), $2000 \mathrm{ppm}$ $(63.33 \%)$ and minimum rooting percentage was in $3000 \mathrm{ppm}$ IBA $(28.33 \%)$ followed by $2500 \mathrm{ppm}(55 \%)$ and control (60\%). However, in relation to the present findings, Jana et al.
(2015) and Ibrahim et al. (2015) found that among different IBA concentrations, 1500 ppm was highest in rooting percentage followed by $2000 \mathrm{ppm}$ and $2500 \mathrm{ppm}$ while the minimum was in control of lemon verbena cuttings. Canli and Bozkurt (2009) also noticed that $1500 \mathrm{ppm}$ had best (87.5\%) rooting percentage followed by $2000 \mathrm{ppm}$ (75.0\%) of IBA treatment in semi hardwood cutting of 'Sarierik' plum. The rooting percentage decreased with the increasing concentration of IBA beyond an optimal level probably due to its inhibitory effect at higher concentration. The increase in rooting percentage may possibly be attributed to division of the root initial cells, which are dependent either upon applied or endogenous auxin content.

Table.1 Effect of IBA level on fresh and dry weight of shoot, rooting percentage and fresh and dry weight of root of Santa Rosa plum cuttings under mist environment

\begin{tabular}{|c|c|c|c|c|c|}
\hline Treatments & $\begin{array}{c}\text { Fresh weight } \\
\text { of shoot } \mathbf{( g )}\end{array}$ & $\begin{array}{c}\text { Dry weight of } \\
\text { shoot } \mathbf{( g )}\end{array}$ & $\begin{array}{c}\text { Rooting } \\
\text { \% }\end{array}$ & $\begin{array}{c}\text { Fresh weight } \\
\text { of root } \mathbf{( g )}\end{array}$ & $\begin{array}{c}\text { Dry weight } \\
\text { of root } \mathbf{( g )}\end{array}$ \\
\hline Control (0 ppm) & 0.21 & 0.089 & 60.00 & 0.029 & 0.009 \\
\hline $\mathbf{1 0 0 0} \mathbf{~ p p m}$ & 0.26 & 0.099 & 71.67 & 0.123 & 0.028 \\
\hline $\mathbf{1 5 0 0} \mathbf{~ p p m}$ & 0.25 & 0.096 & 68.33 & 0.057 & 0.014 \\
\hline $\mathbf{2 0 0 0} \mathbf{~ p p m}$ & 0.23 & 0.088 & 63.33 & 0.053 & 0.014 \\
\hline $\mathbf{2 5 0 0} \mathbf{~ p p m}$ & 0.20 & 0.083 & 55.00 & 0.025 & 0.008 \\
\hline $\mathbf{3 0 0 0} \mathbf{~ p p m}$ & 0.13 & 0.038 & 28.33 & 0.018 & 0.004 \\
\hline $\mathbf{C D} \mathbf{5} \mathbf{5})$ & 0.06 & 0.026 & 13.96 & 0.022 & 0.007 \\
\hline SEm $\mathbf{m}$ & 0.02 & 0.008 & 4.43 & 0.007 & 0.002 \\
\hline
\end{tabular}

Fig.1 Rooting in different IBA concentrations of $1^{\text {st }}$ December planted cuttings

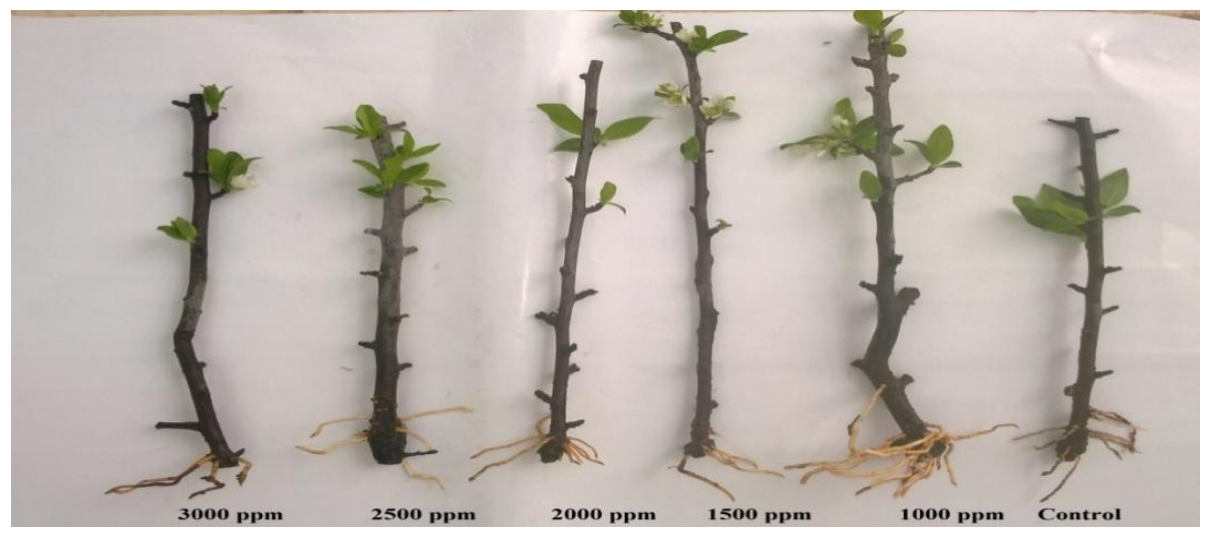


Fig.2 Root and Shoot growth of Santa Rosa plum cuttings under different IBA levels in mist environment

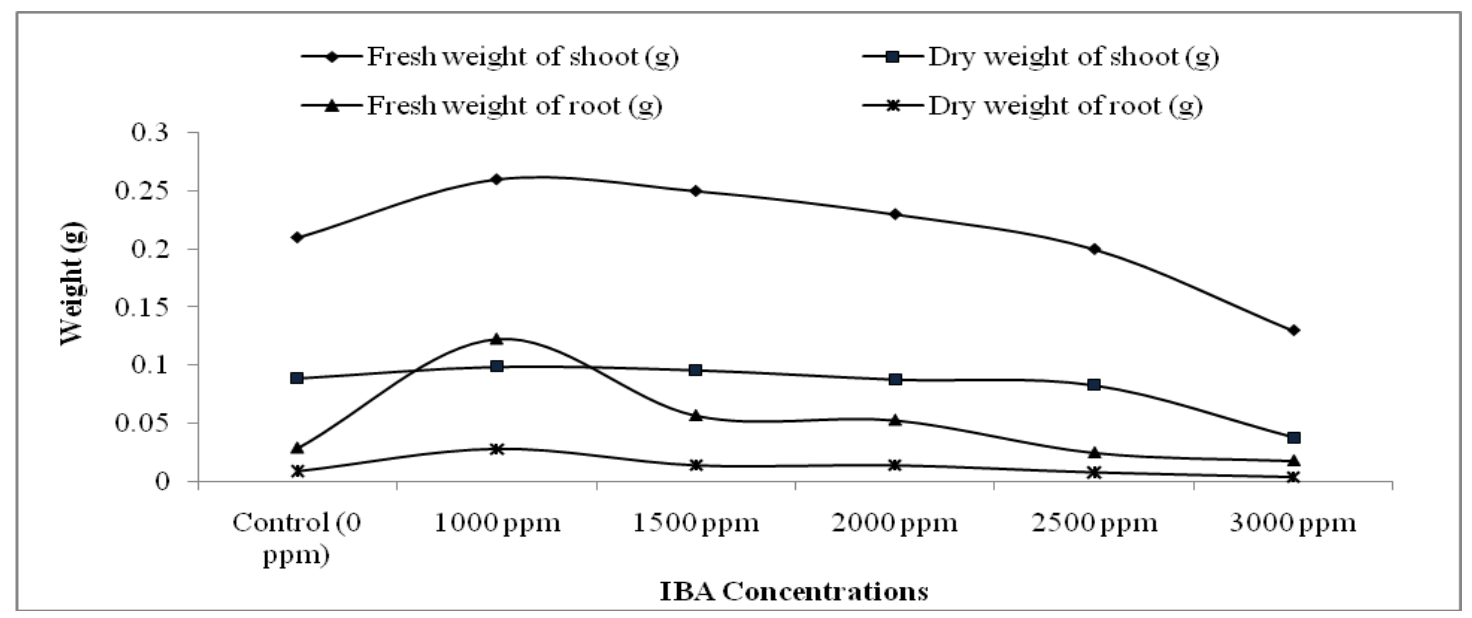

\section{Fresh and dry weight of root}

In fresh weight of root $1000 \mathrm{ppm}$ accounted maximum weight $(0.123 \mathrm{~g})$ followed by 1500 ppm $(0.057 \mathrm{~g}), 2000 \mathrm{ppm}(0.053 \mathrm{~g})$ where as minimum fresh weight of root was in 3000 ppm $(0.018 \mathrm{~g})$ followed by $2500 \mathrm{ppm}(0.025 \mathrm{~g})$ and control $(0.029 \mathrm{~g})$. Dry weight of root was maximum in $1000 \mathrm{ppm}(0.028 \mathrm{~g})$ followed by $1500 \mathrm{ppm}(0.014 \mathrm{~g}), 2000 \mathrm{ppm}(0.014 \mathrm{~g})$ where as minimum dry weight of root was in 3000 ppm $(0.004 \mathrm{~g})$ followed by $2500 \mathrm{ppm}(0.008 \mathrm{~g})$ and control $(0.009 \mathrm{~g})$. Similar findings were observed by Jana et al. (2015) who reported that $1000 \mathrm{ppm}$ had maximum (17.31 g) root weight followed by $500 \mathrm{ppm}$, and the minimum was in control. However, Rajeshwari et al. (2015) observed in their findings that $1500 \mathrm{ppm}$ IBA treatment increased root fresh and dry weight of drumstick cuttings along with coco-peat as media. Galavi et al. (2013) noticed that among four IBA treatments $(0,2000,4000,6000$ $\mathrm{mg} / \mathrm{L}$ ) in grape cutting, $4000 \mathrm{mg} / \mathrm{L}$ contained highest $(0.1125 \mathrm{~g})$ dry weight of root followed by $2000 \mathrm{mg} / \mathrm{L}(0.0985 \mathrm{~g})$, while the minimum $(0.0685 \mathrm{~g})$ was in $8000 \mathrm{mg} / \mathrm{L}$.

More fresh as well as dry weight of root may be due to factors leading to better development of roots including the influence of IBA which helps in promoting root formation.

A trend was noticed in the growth of shoot and roots of Santa Rosa plum cuttings after being treated with different IBA levels and it was found that the cuttings increased in rooting growth and at the same time increment in shoot growth was also observed (Fig.2). This indicates that the proportion of shoots and roots growth increases together and are influenced by the growth of each other.

Hence on the basis of above investigation it may be concluded that among all IBA levels $1000 \mathrm{ppm}$ concentration is the best treatment with respect to rooting and vegetative growth of Santa Rosa plum cutting. Therefore, keeping in view the various advantages of IBA concentration responses in rooting and growth potential of cuttings, IBA application @ 1000 ppm has been recommended for multiplication of Santa Rosa plum.

\section{References}

Ananda, S. A. (1993) Rootstocks of stone fruits. Advances in Horticulture (Ed. K.L. Chadha and O.P. Pareek) 
Malhotra Pub. House, New Delhi. 2: 599-606.

Canli, F.A. and Bozkurt, S. (2009) Effects of indolebutyric acid on adventitious root formation from semi-hardwood cuttings of 'Sarierik' plum. J. Applied Biol. Sci., 3(1): 45-48.

Catherine, M.G.C. and Ginies, R.C. (2009) Comparison of the cell wall composition for flesh and skin from five different plums. Food Chem., 114: 1042-1049.

Galavi, M., Karimian, M.A. and Mousavi, S.R. (2013) Effects of different auxin (IBA) concentrations and plantingbeds on rooting grape cuttings (Vitis vinifera). Annual Review Res. Bio., 3(4): 517-523.

Ibrahim, M.E., Mohamed, M.E. and Khalid, K.A. (2015) Effect of plant growth regulators on the rooting of lemon verbena cutting. Mater. Environ. Sci., 6(1): 28-33.

Jana, B.R., Das, B. and Kumar, S. (2015) Efficacy of IBA and determination of cuttings size in Asian pear (Pyrus pyrifolia L.). Int. J. Plant Res., 5(3): 64-67.

Narula, S. (2018) Effect of growth regulators on rooting of cuttings in plum cv. Kala Amritsari. Scholarly Research Journal for Interdisciplinary Studies, 5/25: 6889-6896.

Rajeshwari, V., Elango, B., Kumar, A.K. and Swaminathan, V. (2015) Impact of IBA on growth and dry matter partitioning of air-layers in annual moringa cv PKM-1. Int. J. Agric. Sci. Res., 5(5): 335-360.

\section{How to cite this article:}

Amit Kotiyal and Anant Ram Nautiyal. 2019. Evaluation of IBA Labels on Vegetative and Rooting Performance of Dormant Cuttings of Plum Cv Santa Rosa under Mist. Int.J.Curr.Microbiol.App.Sci. 8(10): 693-697. doi: https://doi.org/10.20546/ijcmas.2019.810.079 